the experts on the acute abdomen, has given a masterly account on appendicitis - the commonest of all abdominal emergencies.

These scattered remarks should be regarded as an indication of the reviewer's most favourable impressions, rather than as an invidious distinction between varying degrees of excellence of important contributions. He must, however, express some disappointment with the chapter on rheumatoid arthritis. If it had been written by a lesser authority than Dr. W. S. C. Copeman it might, perhaps, have been satisfying.

D.S.L.

\section{STEROID HORMONES AND TUMOURS}

By Alexander Lipschutz, M.D. Pp. xi +309 , with I I I illustrations. London: Baillière, Tindall $\&$ Cox. Baltimore: The Williams and Wilkins Co. I950. $£^{2} 6 \mathrm{~s} .6 \mathrm{~d}$.

This book, although apparently designed for a wider public, will be of interest only to laboratory research workers in the comparatively narrow field which it covers. It consists largely of an account of experiments performed by the author and his associates over a period of some 15 years. The experiments comprised the production of abdominal fibromyomata in guinea-pigs by oestrogens, naturally occurring and synthetic, and the inhibition of this action by progesterone, androgens and adrenocortical steroids. Much allied literature is referred to but, for the most part, is not discussed in a critical fashion. There are about 800 references which should be of assistance to the research worker.

Where the author applies himself to describing his own experimental work he can be understood, but when discussing the wider significance of results and developing arguments in the sphere of speculation he frequently fails to make his meaning clear. This alone makes the book difficult to read and, in addition, there are numerous typographical errors, some of the tables are not clear, some figure legends are confusing or are divorced from the figures to which they refer, and at least one has neither legend nor text reference. One important error of fact was noticed by the reviewer on p. II 3 ; the author states that 'One will remember the work of McIntosh who reported in 1933 production of filtrable tumours by the administration of tar to rats, and later on also in fowls (McIntosh and Selbie, I939).' To the reviewer's knowledge no one has ever claimed to produce filtrable tumours in rats with chemical carcinogens and quite certainly the cited author did not.

Those who read this book should approach it critically.

\section{METHODS OF TISSUE CULTURE}

By RAYMond C. PARKer, Ph.D. 2nd Edition (revised). Pp. xxiv +294 , with I 3 illustrations $\varrho$ London: Cassell and Co. 1950. 57s. 6d.

The first edition of this book described exactly the tissue culture practice of Alexis Carrel, one of the author's teachers and one of the most eminentand authoritative workers responsible for the first great strides in this branch of study. This second? edition has appeared 12 years after the first and $\mathbb{Q}$ the author, with the advantage of mature judgmentw and long experience, is obviously master of his? subject. Also the author's exposition is good and? the book is well written in simple language and is a $\vec{a}$ pleasure to read.

Many laboratory workers, even if not engaged in tissue culture, should read this book, for tissue culture has a wide variety of applications which in clude the study of antibody formation, bacterial in fection, hormonal action, nutrient requirements of living cells, cancer research, blood diseases, embryology and organ growth, cell metabolism, thein action of drugs upon cells, the growth and attenua-o tion of viruses for vaccines and other purposes, the preparation of specimens for the electron microscope음 and the diagnosis of doubtful tumours.

The book begins with an historical introduction 3 which immediately captures the reader's interest Subsequent chapters deal with laboratory design, cleaning and sterilization, and the preparation $8 f$ fo media (this includes an excellent chapter by J. Morgan on the 'Development of Synthetic Medis) in great, but interesting, detail reminiscent of thes ritual demanded by Carrel in his laboratories. However, such detailed description is no disadvantage, for it leads to clarity and comprehensive- $\frac{O}{D}$ ness. The chapters which follow are concerned $\varrho$ with the different types of tissue cultures, illustrated $\overrightarrow{\vec{O}}$ and made interesting by relevant experimental 3 findings. Finally, methods of study of tissue cultures? are described; growth measurements by simpleo mensuration and by metabolic and biochemical studies; histological procedures, which have to be 3 . modified for tissue culture and lastly photomicro-igraphy and microcinematography. There are 3 . numerous illustrations all of which are excellent; the bibliography is adequate, well selected, and does 3 not reach those excesses which usually result from attempts to be uncritically comprehensive.

There are but few adverse criticisms which could $>$ be made and these are of no importance in view of the fact that this book achieves its object so successfully, save one. However, Chapter IV on cleansingo and sterilization seems to be largely unnecessary. $N$ It could be shortened with profit as most of such in-N formation can be found in standard texts on bac- $\omega$ teriological technique. In addition the author does< not appear to be so much at ease when discussing the first principles of sterilization as he is elsewhere in his otherwise excellent book. 